\title{
Comment
}

\section{Abscam, the Judiciary, and the Ethics of Entrapment}

\section{Bennett L. Gershman†}

The government's undercover adventure known as "Abscam"1-or misadventure, depending on one's point of view-is now history. Every public official brought to trial has been found guilty. The courts have passed on the propriety of the government's conduct and, with the exception of a few dissenting judges, have given their imprimatur both to the general operation and the particular techniques used. ${ }^{2}$ Moreover, since the trap successfully ambushed highly-placed individuals, the government's undercover methods have been subjected to close scrutiny by Congress and the public as well. ${ }^{3}$

+ Visiting Associate Professor of Law, Cornell University; Professor of Law, Pace University. This Article is dedicated to Judge James D. Hopkins, and to my wife, Professor Judith Koffler, for all her help.

1. The word is an acronym combining the first two letters of Abdul Enterprises, Ltd., a fictitious Middle Eastern corporation, and the word "scam," a slang expression for a swindle or confidence game. The New York office of the Federal Bureau of Investigation (FBI) created the organization in 1978 as a front to receive stolen property. In 1979, the agents shifted their attention to uncovering political corruption, first in New Jersey, then among members of Congress. During this phase of the investigation, Abdul Enterprises was transformed into a company of Arab sheiks seeking to invest in or emigrate to the United States. See United States v. Myers, 527 F. Supp. 1206, 1209-11 (E.D.N.Y. 1981), aff'd, 692 F.2d 823 (2d Cir. 1982); American Civil Liberties Union, The Lessons of Abscam (Oct. 10, 1982) (unpublished manuscript) [hereinafter cited as ACLU Report].

2. See United States v. Jannotti, 673 F.2d 578 (3d Cir.) (en banc), cert. denied, 102 S. Ct. 906 (1982); United States v. Williams, 529 F. Supp. 1085 (E.D.N.Y. 1981), appeal docketed, No. 821111 (2d Cir. Mar. 26, 1982); United States v. Myers, 527 F. Supp. 1206 (E.D.N.Y. 1981), af'd, 692 F.2d 823 (2nd Cir. 1982). Contra United States v. Kelly, 539 F. Supp. 363 (D.D.C. 1982), appeal docketed, No. 82-1660 (D.C. Cir. June 15, 1982).

3. See, e.g., FBI Undercover Guidelines: Oversight Hearings Before the Subcomm. on Civil and Constitutional Rights of the House Comm. on the Judiciary, 97th Cong., 1st Sess. (1981) [hereinafter cited as Undercover Hearings]; SENATE SELECT COMM. TO STUDY UNDERCOVER ACTIVITIES OF COMPONENTS OF THE DEP'T OF JUSTICE, FINAL REPORT, S. REP. NO. 682, 97th Cong., 2d Sess. (1982); HOUSE COMM. ON STANDARDS OF OFFICIAL CONDUGT, IN THE MATTER OF REPRESENTATIVE RAY. MOND F. LEDERER, H.R. REP. NO. 110, 97th Cong., 1st Sess. (1981); HOUSE COMM. ON STANDARDS OF OFFICIAL CONDUCT, IN THE MATTER OF REPRESENTATIVE MICHAEL J. MYERS, H.R. REP. NO. 1387, 96th Cong., 2d Sess. (1980); Chevigny, A Rejoinder, Nation, Feb. 23, 1980, at 204; Wilson, The Changing FBI-The Road to Abscam, PUB. INTEREST, Spring 1980, at 3. 
Seen as public theater, Abscam cast the three branches of government in a morality play whose plot called for the portrayal of disguised heroes and hidden villains, intricate charades with racial overtones, and lavish scenery against which invitations to corruption set the characters in motion. The federal undercover investigative apparatus combined massive personnel and financial resources with overwhelmingly tempting inducements, all in an effort designed expressly to test the honesty of high-ranking members of a coordinate branch of government." Was Abscam, as its proponents argue, a fair investigation employing accepted crime-fighting techniques, albeit on a large scale and in an unconventional manner, to root out corruption? Or was Abscam, as its critics contend, a pernicious contrivance, using foul means not to prevent crime, but to create it?

These complex and disturbing moral and philosophical questions were resolved by the courts under settled legal principles governing the doctrine of entrapment. This Article suggests that those principles were inadequate to stem the controversy surrounding the Abscam convictions because the principles did not permit an examination of the propriety of the means used by government agents to create the Abscam crimes. Some jurists contend that the entrapment defense should restrain abuses of power by judging the investigative techniques against an objective standard of permissible governmental conduct. ${ }^{5}$ In most states and in the federal courts where the Abscam defendents were tried, however, entrapment is measured by a subjective standard requiring the government to show that the defendant was "predisposed" to respond criminally to undercover government inducements. ${ }^{6}$

4. During the course of the investigation, government agents produced a display of almost limitless riches to impress and entice their targets: lavish parties aboard a luxurious yacht, see United States v. Alexandro, 675 F.2d 34, 36 (2d Cir. 1982), expensive townhouses and hotel suites for entertainment, transportation by private jet and chauffeur-driven limousines, and a bank account deposit of four hundred million dollars, see United States v. Jannotti, 501 F. Supp. 1182, 1193 (E.D.Pa. 1980), rev'd, 673 F.2d 578 (3d Cir.) (en banc), cert. denied, 102 S. Ct. 906 (1982).

5. See, e.g., Sorrells v. United States, 287 U.S. 435, 453-59 (1932) (Roberts, J., concurring). Justice Roberts argued that the entrapment inquiry should focus on the government's methods of investigation rather than on the defendant's culpability and that the government should be forbidden from planning and activating the commission of a crime for the sole purpose of obtaining a victim to be prosecuted and punished. "[T]he consummation of so revolting a plan ought not to be permitted by any self-respecting tribunal." Id. at 454-55. Justice Frankfurter expressed similar concerns in Sherman v. United States, 356 U.S. 369 (1958) (Frankfurter, J., concurring), where he stated that the judicial inquiry should focus on "whether police conduct revealed in the particular case falls below standards, to which common feelings respond, for the proper use of government power." Id. at 382. For a summary of the minority or "objective" view of entrapment, see W. LAFAVE \& A. SCOTT, HANDBOOK ON CRIMINAL LAW \& 48, at 371-72 (1972).

6. See W. LAFAVE \& A. SCOTT, supra note $5, \S 48$, at 371. The majority, or "subjective," entrapment defense has two parts. To succeed with an entrapment defense, the defendant first must show that the government "instigated," "lure[d]," "repeated[ly] and persistent[ly] solicit[ed]," or "[took] advantage of [the defendant's] sentiment." Sorrells v. United States, 287 U.S. 435, 441 (1932). Once the defendant produces some evidence of improper inducement, the government must then demonstrate that the defendant was "predisposed" to commit the crime. See United States v. Sherman, 200 F. 2d 
Part I of this Article surveys the development of these competing threads of entrapment theory. Part II shows how these theories were applied in the Abscam prosecutions. Part III turns to the predisposition test and demonstrates its analytical flaws and its ineffectiveness in restraining the improper use of inducements in undercover investigations. Part IV offers specific suggestions for a federal entrapment statute to remedy these defects. The statute allows an entrapment defense where the undercover techniques used fall outside a narrowly defined range of permissible conduct. If the government's conduct is permissible, the statute nevertheless requires the decision-maker to examine whether the decision to focus an investigation on a defendant was based on a "reasonable suspicion" that the individual was engaged in criminal activity. The advantages of such a statute are twofold. It clearly limits the executive's investigative powers, and it involves the judiciary more fully in checking investigatory excesses.

\section{Two Visions of Entrapment Theory}

Although virtually all judges [agree] that an innocent person who was 'entrapped' . . . into committing a criminal act should not be convicted, there is less agreement on the proper principles underlying the concept . . . and on what factors ... constitute entrapment.

\section{Federal District Judge George Pratt in United States v. Myers."}

Judge Pratt's lament echoes a debate that has endured as long as the entrapment doctrine itself - whether the entrapment defense should focus on the government's investigative techniques or the individual's culpability -and that has created confusion if not incoherence. ${ }^{8}$ The battle lines in

880, 882-83 (2d Cir. 1952) (L. Hand, J.). In identifying the absence of predisposition, courts have examined whether the defendant had "no previous disposition to commit [the crime]," was an "industrious, law-abiding citizen," had no "criminal design," or was "an innocent person" against whom the government "originated" the "criminal design" and then "implant[ed] in the mind of [the] innocent person the disposition to commit the alleged offense." Sorrells v. United States, 287 U.S. 435, 441-42 (1932).

7. 527 F. Supp. 1206, 1219 (E.D.N.Y. 1981), affd, 692 F.2d 823 (2d Cir. 1982).

8. For many years, jurists and scholars have pointed out the doctrine's incoherence. See Sherman v. United States, 356 U.S. 369, 378 (1958) (Frankfurter, J., concurring) (characterizing entrapment decisions as lacking a "formulated basis in reason"); United States v. Becker, 62 F.2d 1007, 1008 (2d Cir. 1933) (L. Hand, J.) (stating that entrapment decisions lack "definite doctrine"); Mikell, The Doctrine of Entrapment in the Federal Courts, 90 U. PA. L. REV. 245, 263 (1942) (noting that doctrine lacks "rational basis"); Note, The Serpent Beguiled Me and I Did Eat: The Constitutional Status of the Entrapment Defense, 74 YALE L.J. 942, 943 (1965) (characterizing entrapment defense as a "failure"). 
this dispute were drawn in 1928 in Casey v. United States. ${ }^{9}$ In Casey, the Supreme Court considered the appeal of a lawyer convicted of smuggling narcotics into a prison. Government agents, suspecting that Casey was smuggling drugs, had arranged for an inmate to approach Casey and ask him for narcotics. After Casey delivered the contraband, he was arrested. The majority declined to scrutinize the tactics used, since the entrapment defense had never been raised by the defendant. ${ }^{10}$ But the opinion included language that indicated approval of the investigation, pointing out that the plot to entrap Casey was no different from "ordering a drink of a suspected bootlegger."11 Justice Brandeis strongly disagreed. In a celebrated dissent, he distinguished situations in which the government involves itself in an ongoing criminal endeavor from those in which the government actually creates the crime. "The Government may set decoys to entrap criminals," he argued, "[b]ut it may not provoke or create a crime and then punish the criminal, its creature." ${ }^{\prime 12}$ Brandeis was less concerned with providing a defense for unwary criminals than with protecting the courts from becoming unwilling parties in the prosecution of individuals whose crimes were induced by governmental officials. To achieve this goal, Brandeis insisted that the government should initiate a "sting" operation only when it had a sufficient factual basis to believe that the defen-

9. 276 U.S. 413 (1928). While Casey stands as the point at which a strong divergence in entrapment theory first appeared, it was not the first time the Supreme Court had addressed the issue. The Court discussed entrapment nearly a century ago in the Decoy Letter Cases. See Price v. United States, 165 U.S. 311 (1897); Andrews v. United States, 162 U.S. 420 (1896); Rosen v. United States 161 U.S. 29 (1896); Goode v. United States, 159 U.S. 663 (1895); Grimm v. United States, 156 U.S. 604 (1895). In those cases, defendants found guilty of using the mails to distribute obscene materials across state lines challenged their convictions on the ground that the contraband in question had been solicited by undercover government agents. The Supreme Court affirmed the convictions without specifically discussing an entrapment defense. The Court distinguished, however, legitimate and illegitimate law enforcement objectives, noting that "it does not appear that it was the purpose to induce or solicit the commission of a crime, but [rather] it was to ascertain whether the defendant was engaged in an unlawful business." Grimm v. United States, 156 U.S. 604, 610 (1895) (emphasis added). Twenty years later, in Woo Wai v. United States, 223 F. 412 (9th Cir. 1915), the Ninth Circuit looked to this language to strike down a conviction. There, government agents suspected that the defendant had knowledge of a scheme by which illegal aliens were brought across the Mexican border into the United States. To force him to divulge the desired information, the agents sought to charge him with a related criminal offense. Thus, they repeatedly asked Woo Wai and others to help transport aliens across the border. The defendant refused these requests on several occasions but finally assented. The court found that the government's conduct violated public policy:

[T] any of the defendants had ever been engaged in the unlawful importation of Chinese. . . . The purpose for which the detective was employed, and the object of the scheme of entrapment, was not to punish men who were suspected of crime; but the whole purpose was to place Woo Wai in a position where he might be compelled to disclose facts of which he was suspected to have knowledge....

Id. at 414.

10. Casey v. United States, 276 U.S. at 418-19.

11. Id. at 419 .

12. Id. at 423 (Brandeis, J., dissenting). 
dant was violating the law. ${ }^{13}$ In Brandeis's view, the defendant's state of mind was irrelevant to the question of whether the prosecution should go forward. Here, then, lay the foundation for an objective approach to entrapment theory.

The Court declined to build on that foundation when the opportunity arose in Sorrells v. United States ${ }^{14}$ and Sherman v. United States. ${ }^{15}$ In both cases, the Court reversed convictions of defendants who had been pressed by government agents to sell them contraband. ${ }^{16}$ While the Court could have relied on the nature of the governmental methods to support its finding of entrapment, the majority in both cases looked instead to the defendants' states of mind, holding that the defendants were "innocent" persons, not predisposed to crime,$^{17}$ who were induced by government offcials to violate the law. ${ }^{18}$ In both cases, however, a minority would have reached the same result by focusing exclusively on the government's methods rather than on the character of the defendant. For them, as for Brandeis, the repugnancy of government misconduct was sufficient to bar prosecution regardless of the defendant's culpability. ${ }^{19}$ Since these were only

13. Id. at 424-25 (Brandeis, J., dissenting).

14. 287 U.S. 435 (1932).

15. 356 U.S. 369 (1958).

16. In Sorrells, the prosecution's evidence showed that a federal prohibition agent visited the defendant and repeatedly asked him for bootleg liquor. Eventually, after the agent had ingratiated himself with the defendant by playing upon friendship and common war experiences, the defendant acquiesced and sold him liquor. Additional evidence produced by the defense showed that the defendant strenuously resisted the agent's importuning, was of good character, and was not involved in the liquor business. In rebuttal, government witnesses testified that the defendant had "the general reputation of a rum-runner." The trial judge did not submit the issue of entrapment to the jury. Sorrells, 287 U.S. at $439-41,452$.

In Sherman, a government informer named Kalchinian met Sherman at a doctor's office where both were being treated for narcotics addiction. After several meetings, Kalchinian, claiming that he was not responding to treatment, asked Sherman whether he knew where to obtain narcotics or whether Sherman could supply him with some. Although Sherman resisted these initial entreaties, he eventually acquiesced and supplied Kalchinian with drugs. In this case, however, the issue of entrapment was submitted to the jury. Sherman, 356 U.S. at 371-72.

17. Sherman, 356 U.S. at 376; Sorrells, 287 U.S. at 442.

18. Sherman, 356 U.S. at 373; Sorrells, 287 U.S. at 441. The Court in both cases ruled that Congress did not intend its penal statutes to apply to innocent persons. Sherman, 356 U.S. at 372; Sorrells, 287 U.S. at 448 . Obviously, the characterization of the accused as an innocent person seduced into crime is not entirely accurate. See Sherman, 356 U.S. at 379-80 (1958) (Frankfurter, J., concurring) ("[w]ithout compulsion and 'knowingly,'... the defendant has violated the statutory command. If he is to be relieved from the usual punitive consequences, it is on no account because he is innocent of the offense described."). Likewise, the argument that Congress intended to prohibit prosecution of innocents is flawed. Id. at 379 (suggestion that Congress did not intend penal statutes to cover tempting of innocent persons is "sheer fiction"); Sorrells, 287 U.S. at 455-56 (Roberts, J., concurring) (calling Congressional intent argument "strained and unwarranted"). Indeed, if Congress's intent were to prevent such prosecutions on the basis of the defendant's intent, it would follow logically that "innocent" victims beguiled by private entrappers also should be excused. See United States v. Russell, 411 U.S. 423, 442 (1973) (Stewart, J., dissenting); Sherman, 356 U.S. at 380 (Frankfurter, J., concurring). For a justification of the private person exception to the entrapment defense, see Park, The Entrapment Controversy, 60 MINN. L. REV. 163, 240-43 (1976).

19. See Sherman, 356 U.S. at 382 (Frankfurter, J., concurring, joined by Douglas, Harlan \& 
minority views, however, the subjective approach became the test for entrapment in the federal courts.

The objective rationale for the entrapment defense, however, was not entirely lost. In Raley v. Ohio ${ }^{20}$ and Cox v. Louisiana, ${ }^{21}$ the Court reversed, on due process grounds, convictions of defendants who had been induced to commit criminal acts that had been dishonestly represented by government agents as lawful. ${ }^{22}$ In response to these rulings, some lower federal courts found entrapment where the defendants, though subjected to excessive governmental inducements, did not fall within the protection of the subjective entrapment test. ${ }^{23}$ The Supreme Court checked this trend, however, in United States v. Russell ${ }^{24}$ and Hampton v. United States. ${ }^{25}$ In Russell, a bare majority reinstated the defendant's conviction and in Hampton, the majority upheld the lower courts' refusal to find entrapment. In so doing, the Court reinforced the subjective nature of the entrapment defense and reaffirmed its rationale. In Russell, an undercover agent infiltrated a drug ring, supplied the defendant with the chemical ingredients necessary to manufacture the drug, and participated in the manufacturing process. ${ }^{26}$ In Hampton, an undercover agent supplied the defendant with drugs that another government agent involved in the operation subsequently purchased. ${ }^{27}$ The lower court in Russell found the government's methods objectionable under entrapment and due process principles. ${ }^{28}$ But the Supreme Court declined to put the tactics at issue.

Brennan, JJ.) ("The crucial question" is whether police conduct falls below standards for proper use of governmental power.); Sorrells, 287 U.S. at 459 (Roberts, J., concurring, joined by Brandeis \& Stone, JJ.) ("The applicable principle is that courts must be closed to the trial of a crime instigated by the government's own agents.").

In his concurring opinion in Sherman, Justice Frankfurter articulated another variation of the entrapment defense-a hybrid approach-that focused on both the government's conduct and the character of the accused. "This test shifts attention from the record and predisposition of the particular defendant to the conduct of the police and the likelihood, objectively considered, that it would entrap only those ready and willing to commit crime." Sherman, 356 U.S. at 384.

20. 360 U.S. 423 (1959).

21. 379 U.S. 559 (1965).

22. In Cox, government officials falsely told the defendant that it would be lawful to demonstrate near a courthouse and then prosecuted him for disorderly conduct when he picketed. In Raley, government officials assured defendants that they had a constitutional privilege to refuse to answer questions of a state investigating commission and then prosecuted them for contempt for their refusal to answer.

23. See United States v. West, 511 F.2d 1083 (3d Gir. 1975) (reversing conviction on due process grounds); United States v. Bueno, 447 F.2d 903 (5th Cir. 1971) (same); United States v. McGrath, 468 F.2d 1027 (7th Cir.), rev'd, 412 U.S. 936 (1973), on remand, 494 F.2d 562 (7th Cir. 1974); United States v. Chisum, 312 F. Supp. 1307 (C.D. Cal. 1970).

24. 411 U.S. 423 (1973).

25. 425 U.S. 484 (1976).

26. United States v. Russell, 411 U.S. at 425-27.

27. Hampton v. United States, 425 U.S. at $486-87$ (recounting defendant's version of the transaction).

28. United States v. Russell, 459 F.2d 671, 673 (9th Cir. 1972) (finding "an intolerable degree of governmental participation in the criminal enterprise"), rev'd, 411 U.S. 423 (1973). 
The defense of entrapment, wrote Justice Rehnquist in Russell, "was not intended to give the federal judiciary a 'chancellor's foot' veto over law enforcement practices of which it did not approve." lice engage in illegal activity in concert with a defendant beyond the scope of their duties," the Hampton court held, "the remedy lies, not in freeing the equally culpable defendant, but in prosecuting the police . . .."30

These rulings illuminate the divergence between the subjective and the objective theories of entrapment. Adherents of the subjective approach insist on tying the availability of the defense to the culpability of the defendant. The investigative techniques used by the government are relevant to the inquiry only insofar as they negate a showing of predisposition. The subjective approach thus permits judicial scrutiny of government conduct only in rare cases. ${ }^{31}$ Proponents of the objective test, on the other hand, advocate scrutiny of investigative methods to determine whether the prosecution may invoke judicial process to obtain a conviction.

\section{Testing the Integrity of Government Officials: The Abscam Investi- gation and Prosecutions}

The differences between the subjective and objective approaches to entrapment assume a more concrete form when viewed in the context of the specific Abscam cases. This section describes the Abscam investigation and compares the results that different courts, looking at similar sets of facts, have reached. The opinions are startling not only in their differences, but also in the way that they highlight the gap in protection resulting from the subjective approach.

\section{A. The Investigation}

Abscam was the code name for a Federal Bureau of Investigations (FBI) undercover operation "designed to test the faith of those in high echelons of Government" by contriving opportunities for corruption. ${ }^{32}$

29. United States v. Russell, 411 U.S. at 435.

30. Hampton v. United States, 425 U.S. at 490.

31. Although the five-judge majority in Russell indicated that outrageous law enforcement conduct would bar the government under due process principles from invoking judicial process to obtain a conviction, 411 U.S. at 431-32, three members of the Hampton plurality (Burger, C.J., White \& Rehnquist, JJ.) would limit the availability of due process protection to situations in which the defendant is not predisposed and government officials have violated the defendant's independent constitutional rights, 425 U.S. at $488-90$. The other members of the plurality, however, (Blackmun \& Powell, JJ.) consider due process protection available even when the defendant has been shown to be predisposed. Thus, under Hampton one could conclude that a majority of the Court viewed due process as a permissible way to control certain investigative abuses. This conclusion may not hold today, however, since Justice Stevens did not participate in the Hampton decision and Justice O'Connor has replaced Justice Stewart, who dissented in Hampton.

32. United States v. Alexandro, 675 F.2d 34, 43 (2d Cir. 1982). 
FBI agents, assisted by Melvin Weinberg, a reputed con man who had recently been convicted of mail fraud, posed as representatives of two wealthy Arab sheiks. The sheiks purportedly wanted to emigrate to the United States and invest in American real estate and businesses. The objective of the operation was to attract public officials who would agree to facilitate the sheiks' objectives and accept generous bribe payments in exchange for their assistance. The sheiks' representations initially attracted the attention of Angelo Errichetti, a New Jersey politician who claimed to have extensive underworld contacts, and Howard Criden, a Philadelphia attorney seeking financing for an Atlantic City gambling casino. Upon learning of the sheiks' interests, the two "formed an alliance" to produce public officials who would be willing to influence other government authorities on the sheiks' behalf. ${ }^{33}$

The alliance proved very effective. Congressmen Michael Myers and Raymond Lederer of Pennsylvania each readily accepted payments of $\$ 50,000 .^{34}$ Congressman John Murphy of New York accepted a briefcase containing $\$ 50,000$ and negotiated financing for a private business venture in exchange for a promise to assist the sheik in immigration matters. ${ }^{35} \mathrm{His}$ colleague, Congressman Frank Thompson of New Jersey, refused a $\$ 50,000$ payment at an initial meeting with the sheik; but at a second meeting, Thompson accepted from the agents a briefcase containing the payment. $^{36}$

FBI agents found that soliciting corrupt conduct from Senator Harrison Williams of New Jersey and Congressman Richard Kelly of Florida was more challenging. The sheiks met with Senator Williams on at least seven

33. United States v. Myers, 527 F. Supp. 1206, 1210 (E.D.N.Y. 1981), affd, 692 F.2d 823 (2d Gir. 1982).

34. Myers, Errichetti, Criden, and Louis C. Johanson, Criden's law partner, shared the $\$ 50,000$ which Myers received. At trial, Myers testified that he had no criminal intent and was only "play acting." He did not raise the entrapment defense. He was convicted of receiving bribes, 18 U.S.C. § 201(c) (1976), using means of interstate travel for unlawful activity, 18 U.S.C. $\$ 1952$ (1976), and conspiracy, 18 U.S.C. $\S 371$ (1976). Errichetti, Griden, and Johanson were convicted of conspiracy and of aiding and abetting Myers on the bribery and interstate travel counts. 18 U.S.C. $\S 2$ (1976). Lederer received only $\$ 5,000$ of his payment; Criden, Errichetti, and Johanson divided the remainder among themselves. Although Lederer raised the entrapment defense, it was rejected by the jury. Like Myers, Lederer was convicted on bribery, conspiracy and interstate travel counts. United States v. Myers, 527 F. Supp. 1206, 1212-13 (E.D.N.Y. 1981), affd, 692 F.2d 823 (2d Cir. 1982).

35. United States v. Myers, 527 F. Supp. 1206, 1212-13 (E.D.N.Y. 1981), affd, 692 F.2d 823 (2d Cir. 1982). At the joint trial of Thompson and Murphy, Thompson was convicted of bribery, 18 U.S.C. $\S 201$ (c) (1976), conspiracy, 18 U.S.C. $\S 371$ (1976), and receiving a criminal gratuity, 18 U.S.C. $\S 201(\mathrm{~g})(1976)$, and was found not guilty of conflict of interest, 18 U.S.C. $\S 203$ (a) (1976). Murphy was found not guilty of bribery, "apparently because [the jury members] were not satisfied that he had fully committed himself to use his influence on the sheik's behalf." United States v. Myers, 527 F. Supp. 1206, 1214 (E.D.N.Y. 1981), aff', 692 F.2d 823 (2d Cir. 1982). He was, however, found guilty of conflict of interest, conspiracy, and receiving a criminal gratuity. Id. Neither defendant raised the entrapment defense at trial.

36. United States v. Myers, 527 F. Supp. 1206, 1237 (E.D.N.Y. 1981), affd, 692 F.2d 823 (2d Cir. 1982) 
occasions over a year. They offered financial assistance for a personal business venture in exchange for the Senator's promise to help obtain government contracts for the venture. Williams repeatedly emphasized that he would not exploit his government service to the advantage of private financial transactions, and he rebuffed plans to conceal profits from the venture from the Internal Revenue Service. ${ }^{37}$ At a final meeting, however, Williams consented to the agents' proposal. ${ }^{38}$

Congressman Richard Kelly's reluctance to accept a bribe also frustrated the FBI. Although Weinberg had been told by an acquaintance that Kelly was likely to assist the sheik in exchange for a bribe, Kelly rejected the agents' initial offer ${ }^{38}$ At a second meeting, after the agents had been warned that Kelly "ain't taking no money ... in his hand,"40 Kelly again stated that he would have "no part in" money arrangements concerning immigration matters. ${ }^{41}$ The agents persisted, however, and finally persuaded Kelly to accept $\$ 25,000$. $^{\mathbf{2}}$

The FBI also used Abscam to investigate local corruption in Philadel-

37. United States v. Williams, 529 F. Supp. 1085, 1091 (E.D.N.Y. 1981), appeal docketed, No. 82-1111 (2d Cir. Mar. 26, 1982). As part of the investigation, Weinberg coached Williams on the appropriate conduct for meeting with the sheik:

In effect, the Senator was told that, whereas both he and the representatives knew that the proposed venture was entirely legitimate, that it would not involve government contracts, and that the Senator had not agreed to and would not be expected to use his official position to advance the interests of the enterprise, it would be helpful if the Senator were to impress the sheik with the importance of his position in the Senate, and his knowledge of the other important persons in the Government.

United States v. Jannotti, 501 F. Supp. 1182, 1194 (E.D. Pa. 1980), rev'd, 673 F.2d 578 (3d Cir.) (en banc), cert. denied, 102 S. Ct. 906 (1982). At a meeting to discuss the proposed business deal with the sheik, Williams in fact emphasized his long career in the Senate and his connections in Washington. Id. at 1195. Weinberg's coaching, however, was not a novel technique. At an August 1979 meeting between Weinberg and attorneys from the Office of the United States Attorney for the District of New Jersey, Weinberg stated "that if he did not put words into the subjects' mouths the government would never be able to make cases." United States v. Myers, 527 F. Supp. 1206, 1235 (E.D.N.Y. 1981), affd, 692 F.2d 823 (2d Cir. 1982).

38. Although Williams raised an entrapment defense at trial, the jury convicted him of bribery, 18 U.S.C. $\S 201$ (c) (1976), receiving a criminal gratuity, 18 U.S.C. $\S 201$ (g) (1976), conflict of interest, 18 U.S.C. $\S 203(a)$ (1976), interstate travel for unlawful activity, 18 U.S.C. $\S 1952$ (1976), and conspiracy, 18 U.S.C. $\S 371$ (1976). In essence, the jury found that Williams either received or agreed to receive stock in a titanium mining venture and financing from the sheik in return for his commitment to help obtain government contracts for the titanium mine. United States v. Williams, 529 F. Supp. 1085, 1091-93 (E.D.N.Y. 1981), appeal docketed, No. 82-1111 (2d Cir. Mar. 26, 1982).

39. United States v. Kelly, 539 F. Supp. 363, 367 (D.D.C. 1982), appeal docketed, No. 82-1660 (D.C. Cir. June 15, 1982).

40. Id. at 368. In a post-conviction opinion, the court quoted at length from a transcript of a recorded conversation between Weinberg and Eugene Ciuzio, a mutual acquaintance of Weinberg and Kelly. Ciuzio ambiguously stated: "He's a kid and I know he's ripe for the first big . . . score. This is a Congressman, ya understand? This ain't . . . a hustler. . . . Don't hand him no . . . money." Id.

41. Id. at 370 .

42. Id. Kelly was convicted by a jury of bribery, 18 U.S.C. $\$ 201$ (c) (1976), conspiracy, 18 U.S.C. $\S 371$ (1976), and interstate travel to commit crime, 18 U.S.C. $\$ 1952$ (1976). Co-defendant Ciuzio was found guilty of aiding and abetting, 18 U.S.C. $\$ 2$ (1976), conspiracy, and interstate travel to commit crime. 
phia. To execute this stage of the operation, Weinberg informed Criden that the sheik wanted to build an elaborate hotel complex in the city if, in accordance with the stereotype of "the Arab mind" propagated throughout the investigation, he "could be assured of the friendship of important government officials." 43 Criden dutifully arranged meetings between the sheik's "representatives" and George Schwartz and Harry Jannotti, president and majority leader, respectively, of the City Council. At separate meetings with Schwartz and Jannotti, an undercover agent posing as a representative of the sheik repeatedly asked the men for assurances that the hotel project would encounter no "problems."44 Both Schwartz and Jannotti repeatedly responded that if the project were legitimate and beneficial for the city, they would support it. ${ }^{45}$ At the conclusion of the meet-

43. See United States v. Jannotti, 501 F. Supp. 1182, 1184, 1196 (E.D. Pa. 1980), rev'd, 673 F.2d 578 (3d Cir.) (en banc), cert. denied, 102 S. Ct. 906 (1982). The judge in Jannotti considered the ethnic stereotyping of the Arab mentality and "the Arab way of doing business" as "[p]erhaps the crucial aspect of the undercover operation" and highly questionable. The agents frequently represented that their principals would not even undertake a legitimate project "unless first assured of the 'friendship' of the persons with whom they were dealing." The sheiks purportedly were impressed with titles, with persons in power and influence; "[ $t$ ]heir concept of 'making friends' was that money had to be paid." Insofar as the Philadelphia aspect of Abscam was concerned, "there was no suggestion that the putative sheik required or expected any violation of the law in exchange for the payment; he merely wished to be assured that he had 'friends' in high places." Id. at 1194.

44. For example, one conversation went as follows:

WALD: Can I go back, ah ah, to my employer, the Sheik and tell him that I dealt with a man, on Wednesday night tell him who he is, dealt with you, Thursday night, explain who you were, what your position is and say he and I conducted a cash business transaction and he guaranteed me, we don't have a problem in Philadelphia. We ah, ah City councils on our side the man has the influence with the Finance Committee, he has influence . . . .

JANNOTTI: You wouldn't, you wouldn't be able to say we don't have a problem. Problems might arise, but problems ah, you might say problems can be solved.

WALD: OK, you can handle those problems we presume.

JANNOTTI: I don't see why not if it's a legitimate, if it's a if it's a legitimate if it's a, if it's a legitimate enterprise, it's a legitimate piece of business.

United States v. Jannotti, 673 F.2d 578, 589 (3d Cir.) (en banc), cert. denied, 102 S. Ct. 906 (1982).

45. At a meeting with the agents, Schwartz stated that no problem would be "insurmountable" " as long as the project " "is a proper project." "When Criden interjected " 'It's going to be legitimate," " Schwartz responded, "That I take for granted, or I wouldn't be here." "The following then occurred:

WALD: Our time frame is growing short, but we don't have those type of problems. We don't have that built-in resentment. Ah . . . . We've talked to Howard, you know, the figures, the dollars we're talking are in the right ballpark. We're....

SCHWARTZ: That's not my prime concern. I'm interested in the City of Philadelphia. I'm interested in a good project. I'm interested in tax rateables. I want to see Center City develop. Especially Center City. There are a few parcels left. Well anything else that's going to add to the tax rateables of the city that's going to create jobs.

Id. at 585-86. The transcript of the conversation at a meeting between the agents and Jannotti included a similar exchange:

WALD: It's a legitimate operation.

JANNOTTI: As long as it's, long as it's a legitimate, legitimate operation. Ya know, any legitimate operation we will fight for because, ah, ya know why shouldn't we fight for a legitimate operation? If the operation is legitimate, it's going to bring a tax base into the City of Philadelphia, it's going to bring employment into the City of Philadelphia, ah, this is, this is basically our job... to try to get as much money into the City of Philadelphia and as many jobs into the City of Philadelphia as we possibly can.

Id. at 587-88. 
ings, Schwartz and Jannotti received $\$ 30,000$ and $\$ 10,000$, respectively. ${ }^{48}$

\section{B. The Abscam Case Law: Four Views of Entrapment and Law Enforcement}

As a result of the Abscam investigation, twenty-five individuals, including one United States Senator, six United States Representatives, and other public officials and lawyers, were indicted for corrupt acts by federal grand juries in New York, Philadelphia and the District of Columbia. Thoughtful judges have characterized the legal issues raised by these cases in strikingly different ways. Although few of the defendants raised the subjective defense of entrapment at trial, all alleged constitutional due process violations based on an objective theory of entrapment. Many of the judges were reluctant to condemn the choices of the Executive in its sphere of competence and rejected the Abscam defendants' claims. Others excoriated the government for the tactics it used. This clash of opinions illuminates the unsettling consequences of a doctrine which is incapable of restraining overreaching investigative abuses.

\section{United States v. Myers ${ }^{47}$}

In post-trial motions to set aside their convictions, defendants Myers, Lederer, Thompson, Murphy, Errichetti, and Criden urged Judge George Pratt, of the Eastern District of New York, to use an objective entrapment standard to evaluate the government's conduct. Alternatively, they urged the judge to apply a due process standard, claiming that the outrageousness of the operation "bar[red] the government," as a matter of due pro-

46. United States v. Jannotti, 501 F. Supp. 1182, 1184 (E.D. Pa. 1980), rev'd, 673 F.2d 578 (3d Cir.) (en banc), cert. denied, 102 S. Ct. 906 (1982). Although Schwartz did not testify at trial, a witness who served as an intermediary between Criden and Schwartz testified that he told Schwartz that, according to Criden, "[t] Criden testified at a post-trial hearing that he told Schwartz "that he would receive a consulting fee." United States v. Jannotti, 673 F.2d 578, 584 n.6 (3d Cir.) (en banc), cert. denied, 102 S. Ct. 906 (1982). When Jannotti received the envelope containing the payment, the agents asked him whether "[the] amount [was] sufficient." Jannotti repeatedly responded that "[w]e won't even discuss it." Id. at 589.

The jury found both Jannotti and Schwartz guilty of conspiring to obstruct interstate commerce in violation of the Hobbs Act, 18 U.S.C. § 1951(a) (1976), and Schwartz guilty of conspiracy in violation of the Racketeer Infuenced and Corrupt Organizations (RICO) Act, 18 U.S.C. $§$ 1962(d) (1976). Id. at 580. With respect to the Hobbs Act conviction, the government had argued that the defendants had conspired to affect interstate commerce by their acceptance of payments in return for their promises to expedite completion of the hotel project. Id. at 594. With respect to the RICO conviction, the government argued that Schwartz conspired with Criden and others to conduct the affairs of Criden's law firm through the payment of bribes to public officials, a pattern of racketeering activity. United States v. Jannotti, 501 F. Supp. 1182, 1187 (E.D. Pa. 1980), rev'd, 673 F.2d 578 (3d Cir.) (en banc), cert. denied, 102 S. Ct. 906 (1982).

47. 527 F. Supp. 1206 (E.D.N.Y. 1981), affd, 692 F.2d 823 (2d Cir. 1982). 
cess, "from invoking judicial processes to obtain a conviction."

Judge Pratt declined both offers. He held that the government needed no factual basis establishing at least a suspicion of criminal activity to undertake an investigation of Abscam's magnitude. ${ }^{49} \mathrm{He}$ also declined to focus on the specific methods used to solicit the Congressmen since the defendants "could simply have said 'no' to the offer"so and avoided criminal liability. ${ }^{51}$ In particular, he rejected the contention that the inducements offered by the government were overwhelming, since "[n]o matter how much money is offered to a government official as a bribe or gratuity, he should be punished if he accepts." 52 Underlying Pratt's support of the government's actions was the great public interest he perceived to be at stake. Official corruption, he noted, posed a danger greater than any foreign enemy:

[T]he government needs to have available the weapons of undercover operations, infiltration of bribery schemes, and "sting" operations such as Abscam in order to expose those officials who are corrupt, to deter others who might be tempted to be corrupt, and perhaps most importantly, to praise by negative example those who are honest and square-dealing. ${ }^{53}$

48. Id. at 1225 .

49. Judge Pratt, following the Second Circuit decision in United States v. Myers, 635 F.2d 932 (2d Cir.) (refusing to quash indictments of Abscam defendant), cert. denied, 449 U.S. 956 (1980), wrote that "the Constitution does not require reasonable suspicion before a congressman may be made the subject of an undercover sting." 527 F. Supp. at 1226.

50. 527 F. Supp. at 1225 .

51. To support this proposition, the court noted that Congressman Edward Patton of New Jersey and Senator Larry Pressler of South Dakota declined bribe offers in front of the FBI cameras. Id.

52. Id. at 1228. The defendants contended that the size of the cash payments $-\$ 50,000$ to $\$ 100,000$-was overwhelming in that it was designed to induce "honest and innocent people to commit a crime they would normally avoid." Id. at 1227 .

53. Id. at 1229. A similar analysis was employed in United States v. Alexandro, 675 F.2d 34 (2d Cir. 1982). There, in an Abscam opinion affirming a bribery conviction of an immigration official, the Court held that the "line between lawful subterfuge and excessive Government involvement is drawn when the end sought cannot be justified by the means used." Id. at 35. Contrasting Alexandro with cases in which violations of due process were found based on the government's use of coercion to obtain evidence, the Court concluded that Alexandro had not been coerced, forced into crime, or drawn inexorably into an elaborate ongoing criminal enterprise. Thus, although it conceded that $\mathrm{Ab}$ scam "indeed was an intricate artifice, a stratagem of convoluted ploys and schemes," it emphatically concluded that "the special relationship between the public and those who serve the Government" demands that "the public will call for, and law enforcement officials will rely upon, special investigative techniques to uncover insidious corruption." Id. at 43.

Members of the office of the United States Attorney for the District of New Jersey disputed the validity of this means-ends analysis. They openly criticized the investigation and argued that the government's methods may have violated the defendants' rights. Judge Pratt cautioned that the New Jersey prosecutors "were jealous of the obvious importance and success of the investigation" and "embarrassed" by an investigation that revealed a "cesspool of corruption" in their own jurisdiction. United States v. Myers, 527 F. Supp. 1206, 1246 (E.D.N.Y. 1981), aff'd, 692 F.2d 823 (2d Cir. 1982). 
The Second Circuit upheld the convictions of the Myers defendants and affirmed the rulings of the district court. ${ }^{54}$

\section{United States v. Williams ${ }^{55}$}

At trial, Senator Williams raised the subjective defense of entrapment, arguing that he was not predisposed to accept the government agents' bribes. Perhaps his strongest evidence on this point was an internal FBI memorandum suggesting that the government's case against Williams was incomplete and that further proof of Williams' criminal predisposition was needed to seek an indictment. The jury, however, was unconvinced and found Williams guilty of the crimes charged. Judge Pratt denied Williams's post-trial motion to set aside the conviction, concluding that the evidence, while not "overwhelming," was sufficient to support the jury's decision." "Merely because some government employees were not overly impressed with the strength of the Williams case as of November 27, 1979," the court held, did not preclude the government "from testing the sufficiency of its evidence before the grand jury in obtaining an indictment, or from convincing a petit jury of the defendant's guilt beyond a reasonable doubt."

\section{United States v. Kelly ${ }^{\mathbf{5 8}}$}

In contrast to Judge Pratt's benign attitude toward the propriety of the Abscam techniques stands the decision of Judge William Bryant, of the District of Columbia, to set aside the jury conviction of Congressman Kelly. While Judge Bryant recognized the need for covert investigations in order to discover crime, he was unwilling to allow the government to pursue that goal without restraints. According to Bryant, the government had unleashed Abscam on Kelly without the "remotest suspicion" of prior, ongoing, or imminent criminal activity on his part. ${ }^{58}$ Giving the govern-

54. United States v. Myers, 692 F.2d at 823. In addition to passing on the issues decided by Judge Pratt, the Second Circuit considered the claim that the allegedly corrupt responses had been so ambiguously solicited that the convictions violated requirements of due process. One defendant argued that the government must make offers of bribes clear when it manages a sting so that the defendant has "the opportunity to say 'No.' "Id. at 843. The court, however, was "unmoved" by the question of whether the investigators' bribes were unfairly obscured since "the agents did not violate due process limits by observing the defendants' ground rules." Id. at 845 .

55. 529 F. Supp. 1085 (E.D.N.Y. 1981), appeal docketed, No. 82-1111 (2d Cir. Mar. 26, 1982).

56. Id. at 1096. While there was no clear-cut evidence showing that Williams had previously engaged in corrupt activity, the court pointed to proof showing that Williams had earlier sought to use his influence to obtain a permit for casinos; "that Williams was willing to receive cash in "expense money' as long as it did not pass to him directly"; and that Williams sought to conceal his involvement in the titanium mine by use of a "blind trust." Id.

57. Id. at 1100 .

58. 539 F. Supp. 363 (D.D.C. 1982), appeal docketed, No. 82-1660 (D.C. Cir. June 15, 1982).

59. Id. at 371 . 
ment the power to act in such circumstances would create a "great potential" for mischief; Bryant considered the absence of a factual basis reason alone "for outlawing the government's conduct." did not stop there. Bryant stated that "the testing should have ended" after Kelley said " 'I got no part in that" " and rejected the bribe. ${ }^{61}$ Bryant explained that "further pursuit and pressure on the part of government agents was nothing short of outrageous. A suspicion-free subject should be exempted from further testing on the basis of winning the first battle against temptation. He should not be required to win a prolonged war of attrition against chicanery." 82

\section{United States v. Jannotti ${ }^{63}$}

Judge John Fullam, of the Eastern District of Pennsylvania, expressed concerns similar to those voiced by Judge Bryant in setting aside the jury convictions of Philadelphia officials Jannotti and Schwartz. He began his analysis within the standard subjective entrapment model. According to the government's evidence, the agents originated the idea of bribe payments and insisted that the hotel project would be abandoned unless Jannotti and Schwartz accepted the sheik's gesture. Given this evidence, Judge Fullam held that there was no factual basis for showing that Philadelphia officials Jannotti and Schwartz were predisposed to commit the crime. The judge therefore ruled that the defendants had been entrapped as a matter of law and were entitled to a verdict of "not guilty."

Judge Fullam then went beyond the subjective approach to assess the government's investigative techniques and its purposes. Setting up a fictitious business entity, hinting that corrupt overtures would be welcome, and even initiating bribe proposals in connection with suspected ongoing corrupt activities ${ }^{65}$-all of these were permissible. But, he held, "it is surely not within the legitimate province of federal agents to embark upon a program of corrupting municipal officials, merely to demonstrate that it

60. Id. at 378 n.58.

61. Id. at 374 .

62. Id. at 376. The court reasoned that since a legislator would most likely be left alone in real life after rejecting a bribe, an undercover investigation that does not simulate that probability does not catch criminals, but creates them. It was therefore necessary to set aside convictions arising from those circumstances: "Governmental manufacture of crime in this sense is as odious, and as prejudicial to a target's rights, as is the governmental snaring of the 'unwary innocent.' "Id. at 377. But see United States v. Myers, 692 F.2d 823, 844 (2d Cir. 1982) ("Undercover agents offering bribes to Congressmen are entitled to simulate the guarded conversation that would be expected of those proposing an unlawful venture. They need not say, 'Congressman, I have here a cash bribe to be exchanged for your corrupt promise to be influenced in your official action.' ") (citations omitted).

63. 501 F. Supp. 1182 (E.D. Pa. 1980), rev'd, 673 F.2d 578 (3d Cir.)(en banc), cert. denied, 102 S. Ct. 906 (1982).

64. Id. at $1200,1205$.

65. Id. at 1204 . 
is possible." ${ }^{B 8}$ Judge Fullam found that the defendants were offered "exceedingly generous" inducements, were not requested to engage in corrupt activity in exchange, and were further compelled by appeals to civic duty. Thus, by enticing defendants with inducements "calculated to overwhelm" them, the agents acted in bad faith, seeking not to detect crime but to promote it. ${ }^{87}$ This conduct violated the defendants' due process rights and required that the jury convictions be set aside.

The Court of Appeals for the Third Circuit, sitting en banc, reversed Judge Fullam's ruling and reinstated the jury verdicts. ${ }^{88}$ The court held that there could not be entrapment as a matter of law and that the jury properly could have found that acceptance of the money by the defendants, even if they did not originate the scheme, showed predisposition. The majority also struck down the lower court's due process rulings and cautioned against a supervisory role for the judiciary in controlling investigative abuses. It warned that "the conduct of agents of the executive branch who must protect the public from crime is more appropriately considered through the political process where divergent views can be expressed in the ballot box."

Two judges strongly disagreed. In a lengthy dissent, they argued that the judiciary must not "shirk responsibility" in regulating impermissible government conduct. They characterized the prosecutions of Jannotti and Schwartz as "classic model[s] of the type of entrapment that our society emphatically condemns"70 and compared the federal agents' techniques to those used by the Gestapo and other secret police organizations. ${ }^{71}$ Clearly convinced that the government had induced Jannotti and Schwartz to accept the bribes, ${ }^{72}$ they argued that the government had failed to make the necessary showing to rebut the defendants' assertion of entrapment and to prove predisposition. ${ }^{73}$

66. Id. at 1205. "[I]n the present case," Judge Fullam noted, "it was the Government, and the Government alone, which created the pattern [of corruption], as well as each bribe." Id. at 1204. In reaching its conclusion, the court relied on United States v. Archer, 486 F.2d. 670 (2d Cir. 1973) (dismissing indictment on ground that federal government contrived to manufacture federal jurisdictional base).

67. United States v. Jannotti, 501 F. Supp. 1182, 1200 (E.D. Pa. 1980), rev'd, 673 F.2d 578 (3d Cir.) (en banc), cert. denied, 102 S. Ct. 906 (1982).

68. United States v. Jannotti, 673 F.2d 578 (3d Gir.) (en banc), cert. denied, 102 S. Ct. 906 (1982).

69. Id. at 609 .

70. Id. at 618 (Aldisert, J., dissenting).

71. Id. at 613 ("The Gestapo were the consummate users of the "honey pot." ").

72. Id. at 617 (characterizing FBI as "consummate manufacturers of crime. They built the plant, they designed the machinery, they operated it, and they covertly solicited the defendants to be customers of their product").

73. Id. at $619-20$. 


\section{The Limitations of Entrapment Doctrine}

The judicial decisions sustaining Abscam illustrate what shall be made more apparent in this section: where it is recognized, the entrapment defense is predicated on logic that is fundamentally incoherent. This incoherence arises at the core of the defense-predisposition-and is one factor creating the diversity of views in the Abscam opinions. What the Abscam cases also show, unfortunately, is that the courts are unwilling to intervene in the face of such problems and impose a stringent objective test. Instead, the police are free to utilize unlimited government resources and irresistible temptations to seduce unsuspecting persons who might not otherwise commit crimes.

\section{A. The Predisposition Dilemma}

Jurisdictions that apply the subjective test of entrapment require the government to prove that the defendant was predisposed to commit the offense and did not act solely on the basis of government inducements. ${ }^{74}$ Because a thorough inquiry into the defendant's actual predisposition would be extremely difficult, a showing of prior criminal inclination ${ }^{75}$ often is deemed sufficient to meet the government's evidentiary burden. At first glance this rule seems inconsistent; the criminal law nowhere else

74. Under the majority subjective rule, entrapment is a question of fact for the jury, See W. LAFAVE \& A. SCOTT, supra note $5, \S 48$, at 373 . In the federal courts, once the defendant has raised the issue of entrapment, the government must disprove entrapment beyond a reasonable doubt. See, e.g., United States v. Pico-Zazueta, 564 F.2d 1367, 1369-70 (9th Cir. 1977); United States v. Silver, 457 F.2d 1217, 1220 (3d Cir. 1972). It is far from clear, however, whether the government is constitutionally required to bear this heavy a burden. See infra note 108 and sources cited therein.

An even less well-settled issue is the question of how much proof the defendant must offer to meet the initial burden of raising the defense. One approach places evidentiary obligations on both the defendant and the government. Under this approach, as described by Judge Learned Hand in United States v. Sherman, 200 F.2d 880 (2d Cir. 1952), the courts must ask (1) whether the agent induced the accused to commit the offense charged in the indictment, and if so, (2) whether the accused was ready and willing to act without persuasion and whether he was awaiting any propitious opportunity to commit the offense. The accused has the burden on the first question; the prosecution has the burden on the second. According to Judge Hand, inducement includes "soliciting, proposing, initiating, broaching or suggesting the commission of the offense charged." It need not include, however, "trickery" or "fraud." Id. at 883 . Under this definition, proof by the defendant of government initiation, standing alone, would satisfy the defendant's evidentiary obligation. See, e.g., United States v. Riley, 363 F.2d 955, 958 (2d Cir. 1966) (inducement "goes simply to the Government's initiation of the crime and not to the degree of pressure exerted"). This broad definition of inducement has been followed in some circuits but has met strong oppositon in others that have defined inducement much more restrictively. In the latter circuits, initiation or solicitation by a government official, without more, is insufficient to constitute inducement for purposes of raising the entrapment defense. See United States v. Burkley, 591 F.2d 903, 912 (D.C. Cir. 1978), cert. denied, 440 U.S. 966 (1979); United States v. Christopher, 488 F.2d 849, 850-51 (9th Cir. 1973); Pierce v. United States, 414 F.2d 163, 165.69 (5th Gir.), cert. denied, 396 U.S. 960 (1969); Kadis v. United States, 373 F.2d 370, 373 74 (1st Cir. 1967).

75. Such a showing might include proof of the defendant's bad reputation, past criminal conduct, or even rumored activities. See United States v. Russell, 411 U.S. 423, 443 (1973) (Stewart, J., dissenting). 
entitles a prosecutor to demonstrate culpability for an act on the basis of the defendant's previous criminal acts. ${ }^{76}$ But it at least comports with common sense that prior criminal inclination will imply the existence of some present criminal predisposition. ${ }^{77}$ The government did not face even this great an evidentiary burden in the Abscam cases, however, since the jury was allowed to infer predisposition simply from the defendant's affirmative response to the government's inducements. For instance, that defendants Myers and Lederer readily accepted cash payments was found to constitute sufficient evidence that they had a preexisting intention to take a bribe. In other words, the defendant is said to be predisposed because he committed the act, and then is held responsible for the act because he was predisposed. The pernicious circularity of this approach is obvious. By allowing the evidentiary gap to be so easily bridged, the doctrine in no way restrains the government in its choice of tactics; in fact, it may actually encourage the government to offer unreasonably exorbitant temptations not only to obtain evidence of the crime but also to overcome the evidentiary hurdle of showing predisposition.

The difficulty with this evidentiary bootstrapping has not been overlooked by more astute members of the judiciary. Judge Learned Hand, for example, was painfully aware of the problem. In United States v. Beck$e r{ }^{78}$ an opinion cited by Judge Pratt as authority for his assertion that acceptance of the bribe was sufficient to show predisposition, ${ }^{79}$ Judge Hand counted the defendant's "willingness to [commit the crime], as evinced by ready complaisance," government entrapment. He carefully qualified this assertion, however, explaining that he did "not wish to commit [the court] to the doctrine that mere readiness is enough" to demonstrate predisposition. The whole entrapment doctrine, he continued, "derives from a spontaneous moral revulsion against using the powers of government to beguile innocent, though ductile, persons into lapses which they might otherwise resist. Such an emotion is out of place, if they are already embarked on conduct morally indistinguishable and of the same kind." ${ }^{\text {81 }}$ Judge Hand elabo-

76. FED. R. EVID. 404(b); C. MCCORMICK, HANDBOOK OF THE LAW OF EVIDENCE $§ 190$ (2d ed. 1972); 1 J. WIGMORE, EVIDENCE $\S \S 55,57$ (3d ed. 1940).

77. This proposition, nevertheless, has serious adverse practical consequences, since it may encourage the government to entrap persons on the basis of status. See United States v. Russell, 411 U.S. 423, 443-44 (1973) (Stewart, J., dissenting) (arguing that past offenders may disproportionately be targeted for solicitation on the theory that they would be unable effectively to raise the entrapment defense).

78. 62 F.2d 1007 (2d Cir. 1933).

79. United States v. Myers, 527 F. Supp. 1206, 1242 (E.D.N.Y. 1981), aff', 692 F.2d 823 (2d Cir. 1982).

80. United States v. Becker, 62 F.2d 1007, 1008 (2d Cir. 1933).

81. Id. at 1009 (emphasis added). 
rated this view in a later case, the Second Circuit opinion in United States v. Sherman. ${ }^{82}$ Predisposition was present, Judge Hand stated, only where the accused was seeking explicitly "to realize his preexisting purpose" and was "awaiting any propitious opportunity to commit the offense."

Using Judge Hand's standard, the juries in the trials of Errichetti and Criden could have properly inferred from the evidence that the defendants previously had engaged in corrupt conduct or that they would have seized any propitious opportunity for corrupt enrichment. Whether the same judgment may be made about defendants Schwartz, Jannotti, and Williams is less certain. Their predisposition, however, was certainly not established simply by showing that they responded to the government's overtures.

Another difficulty with the concept of predisposition is that it encourages, indeed almost requires, judges and juries to adopt what might be considered a crypto-Calvinistic view of human nature. To apply the doctrine with any consistency, courts must frequently divide society into two classes. The first contains the honest, law-abiding, unwary innocents. The second contains the dishonest and corrupt criminals. It is permissible for police to entrap members of the latter class, but not those of the former. Human nature, however, is not so neatly categorized, particularly when the criminal charge involves allegations of political corruption. Official corruption, in contrast to personal, property, or contraband crimes, is characterized by subtle, complex, and frequently ambiguous behavior. ${ }^{84}$ Factors like background, character, emotional disposition, environment, and circumstances-all combine to produce behavior that usually fails to indicate from a moral, psychological, or sociological perspective whether an individual falls at one end or the other of the predisposition spectrum. ${ }^{\mathrm{gs}}$ For example, suppose that a law-abiding but financially strapped public official suddenly finds himself faced with huge medical bills occasioned by family illness. Aware of his predicament, the government lures him into a corrupt act in return for a very considerable cash payment. The temptation is great, and because of his circumstances, he willingly succumbs. Can we say confidently that such person is a predisposed and unwary criminal? Is it fair to say in this case, as Judge Pratt wrote in

\footnotetext{
82. 200 F.2d 880 (2d Cir. 1952).

83. Id. at $\mathbf{8 8 2 .}$

84. This is not to say that bribery invariably is ambiguous, but simply that when dealing with quids, quos, and their relationship, there is much room for disagreement as to whether a criminal act occurred. See, c.g., People v. Cunningham, 88 Misc. 2d 1065, 390 N.Y.S.2d 547 (Sup. Ct. 1976) (dismissing bribery indictment because of uncertainty as to whether transaction was bribe or simply traditional, albeit unethical, political deal).

85. See United States v. Jannotti, 501 F. Supp. 1182, 1191 (E.D. Pa. 1980) (distinction between predisposed and nonpredisposed mental state "not necessarily clearcut"), rev'd, 673 F.2d 578 (3d Cir.) (en banc), cert. denied, 102 S. Ct. 906 (1982).
} 
Myers, that the defendant "could simply have said 'no" "?88 Or, putting the question another way, should the government have the power to tempt previously law-abiding persons, thereby creating a "predisposition" that previously did not exist? Obviously, the current standard fails to take into account the degree and ambiguity of the provocation, the complexity and ambiguity of the response, and the effect of repeated assaults on human resistance to temptation. ${ }^{87}$

\section{B. The Problem of Inconsistent Defenses in Political Corruption Cases}

Additionally, the predisposition problem may be aggravated in prosecutions for political corruption by the procedural rule that sometimes precludes defendants from raising inconsistent defenses. ${ }^{88}$ In the Abscam prosecutions, for example, the rule would have required defendants seeking to claim entrapment first to admit the crime of bribery. Where a transaction is unambiguous, as in drug cases, the rule precluding inconsistent defenses is not problematic. In such cases, claims of entrapment and lack of involvement would be difficult to reconcile. In a corruption case, on the other hand, the transaction that is the gravamen of the crime often is ambiguous; while money may have been exchanged, its characterization as a bribe, a consulting fee, or a campaign contribution may be the critical issue. To require from a defendant who wishes to claim entrapment an admission that the payment was a bribe forces him to make a Hobson's choice. ${ }^{89}$ Again, the benefit of ambiguity redounds only to the prosecution.

\section{Misunderstanding the Significance of Inducements}

Quite apart from the question of predisposition is the problem of the inducement or instigation. Abscam probably stretched the concept of inducement in entrapment law to its limit. Huge amounts of money were

86. United States v. Myers, 527 F. Supp. 1206, 1225 (E.D.N.Y. 1981), aff', 692 F.2d 823 (2d Cir. 1982).

87. Cf. United States v. Barker, 514 F.2d 208, 236 (D.C. Cir. 1975) (Bazelon, J., concurring) (arguing that "[t]he criminal law should be opened up to new behavioral information to better approximate ... the ideal that the law punishes only the free choice to do wrong").

88. While the District of Columbia, Fourth, and Ninth Circuits permit a defendant to raise inconsistent defenses, the remainder generally do not. See United States v. Valencia, 645 F.2d 1158, 1169-72 (2d Cir. 1980). Some Abscam defendants fell under each rule.

Under Hansford v. United States, 303 F.2d 219, 221 (D.C. Cir. 1962), the District of Columbia allows federal criminal defendants both to deny participation in the alleged criminal activity and claim entrapment. The Second Circuit permits the defendant to claim both noninvolvement and entrapment where he introduces no evidence inconsistent with the entrapment defense. See United States v. Valencia, 645 F.2d 1158, 1172 (2d Cir. 1980). The Third Circuit precludes a claim of entrapment where the defendant has already claimed non-involvement in the crime. See United States v. Hill, 655 F.2d 512, 514 (3d Cir. 1981).

89. See United States v. Jannotti, 673 F.2d 578, 614 (3d Cir.) (Aldisert, J., dissenting), cert. denied, 102 S. Ct. 906 (1982). 
dangled as bait. Actual cash payments ranged from $\$ 10,000$ to $\$ 100,000$; $\$ 170$ million was offered to finance the Williams' mining venture; $\$ 150$ million was offered to finance the Philadelphia hotel project; $\$ 10$ million was offered to Williams as his anticipated profit.

Ordinarily, one would expect that the inducements offered by the government should parallel the inducements to which the target presumably has been exposed in his criminal activities, or with which he might reasonably be confronted. Otherwise, as Judge Bryant observed in United States v. Kelly, a law enforcement investigation creates criminals instead of catching them..$^{90}$ More typical of the judicial response, however, was Judge Pratt, who stated "[n]o matter how much money is offered to a governmental official ... he should be punished if he accepts." issue, however, is not that simple. Persistent offers, exorbitant amounts of money, and appeals to emotion or civic duty may seduce a person of ordinary firmness into a compromising position. It is highly debatable whether the inducements in Abscam were of the degree that would permit a fair and informed judgment that the defendant had a preexisting purpose to commit a crime and simply chose this opportunity to realize his ambition.

The excessive inducements used in Abscam become even more objectionable when viewed in light of the means by which the government chose the targets at which Abscam was aimed. Prior to the investigation the government lacked any factual basis to suspect any public official of engaging in criminal activity. The presence of some factual justification-perhaps not even reaching the level of probable cause or reasonable suspicion-would have suggested that the government was using its scarce resources properly, not arbitrarily, and was offering inducements only to those persons who either had shown a willingness to engage in crime or were currently engaged in crime or about to commit a crime. ${ }^{92}$ The absence of any factual basis naturally raises questions about the bona fides of such law enforcement tactics.

The government's ability gratuitously to generate crime through random honesty checks clearly involves unjustified intrusion into citizens' privacy and autonomy. ${ }^{93}$ Such interference, however, is ordinarily restricted

90. United States v. Kelly, 539 F. Supp. 363, 376 (D.D.C. 1982), appeal docketed, No. 82-1660 (D.C. Cir. June 15, 1982).

91. United States v. Myers, 527 F. Supp. 1206, 1228 (E.D.N.Y. 1981), aff'd, 692 F.2d 823 (2d Cir. 1982).

92. See Gershman, Entrapment, Shocked Consciences and the Staged Arrest, 66 MINN. L. REV. $567,612-14$ (1982).

93. It may well be that integrity tests for government officials are necessary to deter misconduct. Whether "[t]he awful instruments of the criminal law," McNabb v. United States, 318 U.S. 332, 343 (1943), should be employed, however, is a wholly separate question. This is not to advocate double standards. Persons who initially are suspected of criminal wrongdoing and who then are investigated 
by procedural safeguards such as the requirement of a warrant. ${ }^{94}$ Ironically, however, the Abscam operation, an intrusion of greater duration and intensity, was not subject to such safeguards. Government agents secretly monitored the Abscam defendants for many months, recorded their intimate conversations and surreptitiously videotaped meetings they attended. No judge authorized such procedures; indeed it is unlikely that any judge would have authorized this type of surveillance absent prior suspicion.

It is critically important to note that such integrity testing could easily become a tool of political oppression, as the dissenters in United States v. Jannotti observed. ${ }^{95}$ Consider how an operation like Abscam, with powerful resources at its disposal, could effectively silence enemies, opponents, and political dissidents. There is no question that innocent persons may be solicited; several were in Abscam. ${ }^{96}$ Those who are strong enough to resist sometimes overwhelming temptation are fortunate. Others, however, may yield, producing a class of unwitting government-fashioned criminals. Such undercover infiltration and provocation may also produce a police state mentality, evoking fear, paranoia, and mutual distrust among friends and colleagues. Historically such tactics have been favored by totalitarian regimes $^{27}$ - their use in Abscam has frightening and far-reaching implications that most courts have overlooked or have chosen to ignore.

\section{A Federal Entrapment Statute}

As the Abscam prosecutions demonstrate, doctrinal incoherence and judicial deference to the government's choice of undercover techniques leave all citizens relatively unprotected against certain investigative abuses. There are, however, nonjudicial means of restraining abuse by law enforcement authorities. One such means is the issuance of administrative guidelines. For example, in the aftermath of Abscam, the United States Department of Justice and the FBI issued comprehensive guidelines "to establish clear and workable procedures for the authorization and review of undercover operations at appropriate levels in both the FBI and the

and detected, properly should be subject to traditional criminal penalties. Persons who fail honesty tests conducted at random are in a different category, and perhaps should be dealt with differently.

94. See, e.g., Katz v. United States, 389 U.S. 347 (1967) (requiring a warrant for electronic cavesdropping); Aguilar v. Texas, 378 U.S. 108 (1964) (listing requirements for valid search warrant).

95. United States v. Jannotti, 673 F.2d 578, 612-13 (3d Cir.) (Aldisert, J., dissenting), cert. denied, 102 S. Ct. 906 (1982).

96. Three legislators brought to the agents by the middlemen rejected the bribes. See United States v. Myers, 527 F. Supp. 1206, 1225 (E.D.N.Y. 1981), aff', 692 F.2d 823 (2d Cir. 1982).

97. See H. ARENDT, THE ORIGINS OF TOTALITARIANISM 419-37 (1966); W. SHIRER, THE RISE AND FALL OF THE THIRD REICH 273 (1960). 
Justice Department." more restrictive than those required by the law of entrapment or the constitutional principles of due process," ${ }^{298}$ the protection they provide, especially in the context of an operation like Abscam, is illusory. Most significantly, they contain no explicit sanctions for noncompliance. Consequently, there are few incentives for potentially offending officials to conform their conduct to acceptable investigative behavior. Thus, although the federal guidelines point in the right direction, they are ultimately of little practical utility in regulating undercover operations. ${ }^{100}$

Given the present state of affairs, the obligation to curb abuses of investigative power lies with legislation. The Supreme Court has invited a legislative response ${ }^{\mathbf{1 0 1}}$ and the special Senate committee appointed to study the Abscam investigation has recommended the introduction of legislation providing for a limited objective entrapment defense. ${ }^{102} \mathrm{~A}$ statutory rem-

98. DEPARTMENT OF JUSTICE, OFFICE OF THE ATTORNEY GENERAL, ATTORNEY GENERAL'S GUidelines ON FBI UNDERCOVER OPERATIONS 1 (Press Release Jan. 5, 1981) (on file with Yale Law Journal).

99. Id. at 2.

100. For example, the guidelines attempt to minimize the possibility of overly persistent solicitation by limiting the duration of an undercover operation initially to six months. See Undercover Hearings, supra note 3 , at 120 . While they therefore might prevent an agent from pressuring a target like Senator Williams for as long as a year until he capitulates, they also might permit an operation to be extended indefinitely by official authorization. The guidelines also enumerate a dozen "sensitive circumstances" in which officials should scrutinize the propriety of undercover tactics. These include situations where agents might have to commit crimes, infiltrate political groups, or penetrate privileged professional or confidential relationships. There are not, however, explicit prohibitions on such activities; rather there is a requirement that the questionable conduct be authorized by a high-ranking official. Id. at 116-17.

To be sure, the guidelines could have required a warrant from a judicial officer, instead of highlevel agency approval. Cf. Gershman, supra note 92, at 633-37 (proposing warrant for staged arrest). Practical considerations alone might justify the use of a warrant in an investigation as sensitive as Abscam. Since a neutral magistrate would not be subject to the internal pressures exerted on an agency official, advance judicial scrutiny and approval could significantly reduce the potential for arbitrary and overreaching government conduct. Moreover, the realization that a court had authorized the operation and that the government had made a responsible attempt to minimize arbitrary behavior might temper potential public and judicial criticism. It is unlikely, however, that police or prosecuting officials would subject their plans to judicial approval unless legally required to do so.

The guidelines' treatment of the problem of excessive or persistent offers also is unsatisfactory. The guidelines require that there be a "reasonable indication" that the undercover operation will reveal illegal activities, that the criminal nature of the proposed activity be "reasonably clear" to potential targets, and that the nature of the inducements be "not unjustified" in view of the character of the illegal transaction. The guidelines, however, do not give content to these standards. See Undercover Hearings, supra note 3 , at 13 (testimony of Professor Louis Seidman).

101. See United States v. Russell, 411 U.S. 423, 433 (1973).

102. This recommendation largely mirrors the formulations proposed in the Model Penal Code and the original draft of the new Federal Criminal Code. See MOdEL PENAL CoDE $\S 2.13$ (Proposed Official Draft 1962); U.S. NATIONAL COMM. ON REFORM OF FEDERAL LAWS, A PROPOSED NEW FEDERAL CRIMINAL CODE $\$ 702(2)$ (1971). Under the recommendations contained in the final report of the Senate Select Committee to Study Undercover Activities of Components of the Department of Justice, the defendant would be acquitted if he could prove by a preponderance of the evidence that he was induced by government agents to commit an offense and that the government used "methods that more likely than not would have caused a normally law-abiding citizen to commit a similar offense." N.Y. Times, Dec. 17, 1982, at A29, col. 1. 
edy would be constitutionally significant for two reasons. First, as a legislative imperative, it would overcome the judiciary's oft-expressed reluctance to review the conduct of law enforcement authorities. Second, it would help safeguard the individual rights of citizens by curbing the excesses of those authorities. To do this, however, the statutory scheme must provide both principled limitations on government solicitation of criminal activity and clear, logical standards by which to evaluate that conduct. These goals can be most effectively accomplished by constructing a statute that requires the fact-finder to analyze the government's undercover techniques rather than the defendant's mental state and that specifically mandates consideration of whether the methods used were unreasonable, whether the law enforcement operation was initiated in bad faith, and whether the actions taken in the course of the investigation caused or threatened substantial harm to individuals and society. A statute that permits this inquiry will fill the analytic gap currently found in entrapment doctrine. By way of a preliminary contribution to this effort, I propose the following statutory language:

\section{Unlawful Entrapment}

A law enforcement official or his agent commits unlawful entrapment if for the purpose of obtaining evidence for a criminal prosecution he induces any person to engage in criminal activity by methods that are unreasonable or undertaken in bad faith, or that cause or threaten substantial harm to individuals or society, or that induces a nondisposed person to engage in criminal activity.

\section{Definitions}

1. Induce: A law enforcement agent induces another person to engage in criminal activity if the agent initiates, instigates, or otherwise proposes the criminal activity.

2. Nondisposed: An individual is nondisposed to engage in crime when, prior to being induced, he is not reasonably suspected of engaging in, nor reasonably suspected of intending to engage in, criminal activity.

3. Unreasonable Methods: Unreasonable investigative methods include, but are not limited to:

(a) violations of individual constitutional rights; or

(b) excessive and unwarranted intrusions on confidential, privileged, or protected relationships; or

(c) the unexcused commission of crime by law enforcement officials or their agents; or

(d) the use of inducements that would cause a normally law-abiding person to engage in criminal activity. 
4. Bad Faith: Bad faith may be demonstrated by, but is not limited to:

(a) showing that the predominant purpose of a law enforcement operation was to induce nondisposed persons to engage in criminal activity; or

(b) showing that government officials failed to use reasonable procedures to ascertain whether inducements were offered only to individuals currently engaged in, or reasonably suspected of engaging in, criminal activity; or

(c) showing that the law enforcement agent induced criminal activity for reasons demonstrably unrelated to legitimate law enforcement objectives; or

(d) showing that government officials failed to use reasonable procedures to minimize the likelihood of causing substantial harm.

5. Substantial Harm: Substantial harm includes, but is not limited to:

(a) serious injury to any person; or

(b) excessive and unwarranted damage to the property of any person; or

(c) excessive and uncontrolled distribution of contraband or dangerous substances.

The inquiry into governmental conduct expresses our intuitions of the principled bases upon which law enforcement officials should conduct their activities. The "reasonableness" criterion will encourage courts to avoid the unsatisfactory "end-justifies-the-means" analysis employed by the Abscam courts. ${ }^{103}$ The substantial harm test allows the court to consider the independent effects of undercover operations and to punish conduct inimical to the interests of society. The bad faith inquiry goes a step further and punishes impermissible techniques or motives on the government's part even if substantial harm or nondisposition cannot be shown. The "bad faith" inquiry thus provides an additional incentive for executive officers to conduct undercover investigations responsibly.

By requiring some reasonable suspicion of criminal activity, the statute allows courts to dispense with the predisposition inquiry and to use instead the concept of "reasonable suspicion" to test whether an individual is "nondisposed." Reasonable suspicion is a standard lower than the Fourth Amendment's requirement of probable cause for warrantless ar-

103. The reasonableness standard is used elsewhere as a test of the constitutionality of investigative techniques that intrude into citizens' lives. See Rochin v. Galifornia, 342 U.S. 165, 172 (1957) (due process requires "evaluation based on a disinterested inquiry"); United States v. Brown, 635 F.2d 1207, 1214 (6th Cir. 1980) (police decision to allow commission of crimes to catch other members of burglary ring not violation of due process). 
rests and searches. ${ }^{104}$ Rather, it is the level of knowledge that permits a police officer constitutionally to stop and question a person on a public street. ${ }^{105}$ The statute thus contemplates that the selection of an investigation's target be decided on a factual basis similar to that required when the government routinely confronts citizens in public. Since undercover operations frequently are far more intrusive and of longer duration than a cursory stop on a public street, the standard allows the government a fair degree of latitude without permitting it to intrude on the lives of innocent individuals.

There are considerable advantages to the use of this statute. While focusing attention on the government methods themselves, the statute nevertheless affords ample flexibilty in the achievement of legitimate law enforcement goals. The statute plainly presupposes that undercover operations are a necessary and permissible method of crime detection, particularly where covert crimes such as narcotics offenses or corruption are the objects of the investigation. ${ }^{108}$ For example, it would not prohibit traditional "sting" operations nor preclude government agents from infiltrating ongoing criminal activity. In the former instance, the undercover objective is to create a fictitious entity that provides a ready criminal opportunity for persons already engaged in criminal activity or seeking to engage in such activity. The. "sting" consists of controlling the simulated conditions whereby evidence of guilt may be established. With the infiltration, the undercover agent does not solicit but presumably merely participates in ongoing criminal activity. What the statute does prohibit, however, is the offering of inducements by government officials to persons not reasonably suspected of criminal activity.

The statutory proposal leaves unanswered certain procedural questions as to who bears the burden of going forward or the risk of nonpersuasion on the various elements of the defense. ${ }^{107} \mathrm{My}$ own view is that both the burden of going forward and the risk of nonpersuasion on the issue of government misconduct should be placed on the defendant. Placing the evidentary burden upon the defendant would be constitutional since entrapment does not negate an element of the crime and so does not ease the government's burden of proving every element of a crime beyond a reasonable doubt. ${ }^{108}$ By raising the defense, the defendant ordinarily admits

104. See Draper v. United States, 358 U.S. 307, 310-13 (1959).

105. See Terry v. Ohio, 392 U.S. 1, 20-27 (1968); see also United States v. Cortez, 449 U.S. 411, 417-18 (1981) (warrantless stopping of vehicle permissible where facts afford objective basis for suspicion).

106. See Hampton v. United States, 425 U.S. 484, 495 n.7 (1976) (Powell, J., concurring); United States v. Russell, 411 U.S. 423, 432 (1973).

107. See supra note 74 for the allocation of burdens under present entrapment law.

108. See In re Winship, 397 U.S. 358, 364 (1970) (due process clause protects accused against 
that he committed the acts necessary for criminal liability and is not seeking to justify or excuse his conduct. Rather, the defendant is seeking to object to the methods used by the government official in tempting him into a crime that he otherwise would not have committed. Since the defense is not constitutionally mandated, a legislature might consider it a fairer and presumably more attractive compromise to provide an ameliorative defense but to require the beneficiary to bear the burden of proof at least on some elements. ${ }^{109}$ Other principles of burden allocation, like access to the relevant proof, might, of course, dictate an opposite result. ${ }^{110}$

An application of my proposed statute probably would have produced decidedly different results in the Abscam cases. First, proof that persons who were not reasonably suspected of engaging in criminal activity were induced to commit crimes would constitute unlawful entrapment. Since most courts concluded that the government had no apparent factual basis to suspect any defendant of engaging in crime at the time he was approached, the entrapment defense would be successful. Second, the nature and amount of the inducements offered-particularly to Williams, Jannotti, and Schwartz-might be viewed as sufficiently excessive as to induce normally law-abiding persons to respond criminally. Accordingly, such inducements would constitute an "unreasonable method" under the statute and constitute an unlawful entrapment. Finally, if the government's predominant purpose was to induce nondisposed persons like Kelly, Jannotti, and Schwartz to engage in criminal activity, or if the operation was unrelated to legitimate law enforcement goals, as Judge Fullam concluded in United States v. Jannotti, then the government's "bad faith" would provide a separate basis for finding unlawful entrapment.

\section{Conclusion}

Abscam raised complex and troubling questions about our constitutional form of government. The investigation may have uncovered latent corruption, but at the cost of possibly impairing the integrity of other leg-

conviction except upon proof beyond reasonable doubt of every fact necessary to constitute crime). While there remains a question as to which facts are covered by the reasonable doubt rule, compare Mullaney v. Wilbur, 421 U.S. 624 (1975) (invalidating state statute requiring the defendant to prove provocation as defense to murder), with Patterson v. New York, 432 U.S. 497 (1977) (upholding state statute requiring defendant to prove "extreme emotional disturbance" as defense to murder), it is fairly clear that issues not going to the defendant's culpability fall outside the rule's scope. See Underwood, The Thumb on the Scales of Justice: Burdens of Persuasion in Criminal Cases, 86 YALE L.J. 1299, 1343 (1977).

109. See People v. Patterson, 39 N.Y.2d 288, 306, 347 N.E.2d 898, 910, 383 N.Y.S.2d 573, 584 (1976) (Brietel, C.J., concurring); Underwood, supra note 108, at 1331-32.

110. See Underwood, supra note 108, at 1333-36 (explaining rationale of burden allocation in alibi defense). See generally Jeffries \& Stephan, Defenses, Presumptions and Burden of Proof in the Criminal Law, 88 YALE L.J. 1325 (1979) (suggesting framework for determining constitutionality of defenses and presumptions in criminal law). 
Abscam and Entrapment

islators and the legislative process generally. And the judicial branch, while purporting to balance the executive's use of power against constitutional commands, failed to articulate constitutional or legal restraints on the government's undercover methods.

Restoring the balance of power is now the responsibility of Congress. Through legislation aimed at curbing excesses of law enforcement power, Congress has the opportunity to provide principled and meaningful standards to limit the misuse of such power, as well as to provide a means for citizens to vindicate claims of abuse. 


\section{The Yale Law Journal}

Volume 91, Number 8, July 1982

\section{Richard L. Revesz Editor-in-Chief}

\author{
Steven G. Galabresi \\ Note \& Topics Editor \\ José M. Berrocal \\ Davison M. Douglas \\ Cynthia L. Estlund \\ Carl H. Loewenson, Jr. \\ Note Editors
}

Robert E. Cooper, Jr. Managing Editor

Martha Grace Duncan George Ellard

Michele S. Hirshman

Eric L. Lewis

H. J. van der Vaart

Article \& Book Review Editors
David E. Brodsky

Sarah Dillian Cohn

Nicholas M. De Feis

Doron A. Henkin

Candice Hoke

C. Bruce Baker

Thomas H. Bell

Gregg Bloche

Michael T. Brady

Troy Brennan

David A. Broadwin

Peter W. Devereaux

Stephen W. DeVine

Joseph A. Franco

Roger George Frey

Nancy I. Greenberg

Business Manager: Pamela Standish
Michael A. Jacobs Valerie A. Lambiase Janet R. Langford Gene J. Oshman

\section{Senior Editors}

David A. Hansell

Joan E. Hartman

Eugene G. Illovsky

Samuel Issacharoff

Roberta M. Kania

Andrew A. Lance

Gary S. Lawson

Peter B. Marrs

Meridee Moore

Susan R. Necheles
Robert D. Richman

William H. Rooney

Victoria P. Rostow

Don Sparks

Wendy Warring

Daniel R. Ortiz

Linda M. Owens

Wes Parsons

Patrice M. Pitts

Manley W. Roberts

Bennett C. Rushkoff

Jeffrey W. Sacks

Daniel Smirlock

Pat Shapiro Spengler

Susan J. Swift

Gene A. Turk, Jr.

Editors

Editorial Assistants: Claudia Shapiro Liz Doyle

Beth A. Eastlick Natalie Ford

\section{Student Contributors to This Issue}

Richard Bartlett, United Charities and the Sherman Act

David E. Brodsky and Nicholas M. De Feis, Facilitating Administrative Agency Access to Grand Jury Material

George Ellard, Constitutional Rights of the Corporate Person

H. J. van der Vaart, Redefining Insurance: Distinguishing Between Life Insurance and Investment Under Volatile Inflation 